\title{
The Greatly Affect of Leadership, Encouragement and Discipline in Teacher Success
}

\author{
Madyahya $^{\left.1^{*}\right)}$, Happy Fitria ${ }^{2}$, Syaiful Eddy ${ }^{2}$
}

\author{
${ }^{1}$ SD Negeri Ramba \\ ${ }^{2}$ Universitas PGRI, Palembang, Indonesia \\ ${ }^{*}$ Corresponding author. Email: madyahyalillah@gmail.com
}

\begin{abstract}
The objective of this analysis was to evaluate the impact of the Headmaster Leadership Style, Teacher Work Motivation and Teacher Discipline on Teacher Success in partial and simultaneous tests. The total population of teachers in the Babat Supat District of Musi Banyuasin Regency is 294 teachers. Removing the number of samples using the method of sampling in order to obtain a sample size of 75 teachers. Respondents were some of the Babat Supat District teachers, Musi Banyuasin Regency. Study was carried out by circulating surveys using a 5-point Likert - type scale to calculate 60 items of the declaration. The methodology shown is multilinear regression. The outcome of the research can be concluded that the influence of the principal's style of leadership, the motivation of the teacher to work and the discipline of the teacher whether in part or concurrently influence the appearances of the teachers in SD Negeri Babat Supat District of Musi Banyuasin Regency.
\end{abstract}

Keywords: Leadership, Motivation, Discipline and Performance

\section{INTRODUCTION}

One of the characteristics of the educational crisis in Indonesia is that teachers have not been able to demonstrate adequate job efficiency. This indicates that the success of teachers is not completely accompanied by an appropriate degree of competence of proficiency, therefore comprehensive efforts need to be made to improve teacher competence [1].

The principal's style of leadership is expected to master and have the ability to motivate his subordinates so that the primary school principal can influence and understand what his subordinates need [2]. The success of school management is largely determined by the use of human resources [3]. Ruliaty's research [4] It suggests that the effective leadership of Headmaster's has a direct good impact on the success of the teacher. Another research indicates that the Headmaster's leadership style has an impact on the success of English teachers [5].

On the basis of behavioral theory [6], many elements have an impact on teacher performance. Some of the elements that are often overlooked are the leadership style of the principal and the motivation of the teacher to work. School principals often fail to recognize the importance of the style of leadership they apply in relation to teacher performance [7]. Handayani's research shows there is a major impact between the motivation of the educator to work and the success of the teacher [8]. Supeno et al's research on the impact of encouraging classwork on the performance of English teachers [9].

The author also obtained data that out of 35 schools, there were 5 schools with a very uneven proportion of the number of students and teachers, such as SDN 2 Ramba Jaya, where there were only 23 students, with 8 teachers, and several other schools with almost the same condition. This indicates that there is a problem with the leadership of the principal, where the leadership did not make optimal use of the teachers in the school. Due to the route being taken, the condition of long distances is that the area is isolated.

Another problem is that there are about $10 \%$ of teachers who never create innovations in learning, such as teachers who have not applied aspirational learning methods to students. Thus, if this problem occurs continuously, it will have a less than optimal impact on the learning process. 


\section{METHODS}

This method of study is survey data, according to Imansyah et al [10], which focuses upon this analysis of objective phenomena to be quantitatively investigated. The sample period is the main data. The study consisted of three independent variables, namely leadership $\left(X_{1}\right)$, discipline $\left(\mathrm{X}_{2}\right)$, motivation $\left(\mathrm{X}_{3}\right)$, while the variable was the output of the educator $(\mathrm{Y})$.

Quantitative data collection analysis has been performed. This analysis approach uses a partial method and simultaneous regression methods used to analyze or test the hypothesis if the author decided to define the impact, or the correlation between the objective variable in the model. The population of this study was all educators in the SD Negeri Babat Supat District, which consisted of 294 teachers. This sample was taken by researchers using probabilities sampling techniques.

The data collection technique used in this study was based on interviews, questionnaires, observations and a combination of the three. In this study, the data collection technique used by the researcher was a questionnaire to be answered by the respondent on the basis of the situation, observation and documentation they experienced. Data collected by using the Likert scale model. The predictive analytics methodology provided simple regression and linear regression with SPSS For Windows version 25.00.

\section{RESULTS AND DISCUSSION}

\section{The Greatly Affect of Leadership on teacher success}

The pattern of interaction between headmaster leadership and teacher success is expressed in the form of linear regression $\mathrm{Y}=12,142+0,378 \mathrm{X}_{1}$; the survey approach of the linear regression are being discussed in the following section.

Table 1.

The significance of principal leadership on teacher work performance

T Test

\begin{tabular}{|c|c|c|c|c|c|}
\hline \multirow[b]{2}{*}{ Model } & \multicolumn{2}{|c|}{$\begin{array}{c}\text { Unstandardized } \\
\text { Coefficients } \\
\text { Std. }\end{array}$} & \multirow{2}{*}{$\begin{array}{c}\text { Standardized } \\
\text { Coefficients } \\
\text { Beta } \\
\end{array}$} & \multirow[b]{2}{*}{$\mathbf{t}$} & \multirow{3}{*}{$\frac{\text { Sig. }}{0.044}$} \\
\hline & B & $\begin{array}{l}\text { Std. } \\
\text { Error }\end{array}$ & & & \\
\hline $1 \quad$ (Constant) & 12.142 & 5.939 & & 2.045 & \\
\hline leadership & 0.738 & 0.107 & 0.629 & 6.915 & 0.000 \\
\hline
\end{tabular}

a. Dependent Variable: Performance

Centered on the measure of the value of the headmaster leadership component to the success of teachers in the Babat Supat District, the $t$ value is 6.915> the $t$ table price is 1.9944 where the $t$ value is greater than the $\mathrm{t}$ table and the significance value is 0.000 less than 0.05 , so Hol agreed that there was a major impact on the main steering variable.

The leadership of the Principal should implement the principles of democratic leadership in any activity by involving all parties who have an interest in, or have a direct relationship with, the Principal. This principle should be applied consciously and sincerely, starting with the planning of school programs, the implementation and evaluation of results and the implementation of the program itself. The leader must also be in a position to cooperate with all parties in the school environment.

This analysis is in line with studies conducted by Imansyah et al [11]. Results have shown that: (1) primary leadership style has a strong and major influence on the success of the teachers in SD Negeri at Muara Enim Regency (2) the presence of the student council has a positively and significantly impact on the success of the teachers in SD Negeri at Muara Enim
Regency, and (3) the school leadership and the involvement of the student council together have a positively and significantly impact on the effectiveness of the teachers in SD Negeri at Muara Enim Regency. Suratman et al [12] research results: Research 1) there is no impact on the success of the teacher by principal leadership; 2) there is an effect on the performance of the teacher by the skill of the teacher, and 3) there is at the same time an effect of the main leadership and competence of the teacher on the performance of the teacher. This paper leads to enhancing teacher quality through primary leadership and teacher expertise.

\section{The effect of teacher discipline on teacher performance}

The pattern of relationship between principal leadership and teacher success is represented in the form of the regression model $\mathrm{Y}=12,142+0,378 \mathrm{X}_{2}$. The Regression Equation Significance Test can be seen in the table below. 
Table 2.

The significance of teacher discipline variables on teacher work performance

\begin{tabular}{|c|c|c|c|c|c|}
\hline \multirow[b]{2}{*}{ Model } & \multicolumn{2}{|c|}{$\begin{array}{l}\text { Unstandardized } \\
\text { Coefficients } \\
\text { Std. }\end{array}$} & \multicolumn{3}{|l|}{$\begin{array}{l}\text { Standardized } \\
\text { Coefficients }\end{array}$} \\
\hline & B & $\begin{array}{l}\text { Std. } \\
\text { Error }\end{array}$ & Beta & $\mathrm{T}$ & Sig. \\
\hline $\begin{array}{ll}1 & \text { (Constant })\end{array}$ & 7.965 & 5.556 & & 1.434 & 0.156 \\
\hline discipline & 0.805 & 0.099 & 0.690 & 8.146 & 0.000 \\
\hline
\end{tabular}

Centered on the statistical significance of the motivating variable of the teacher for the success of elementary school teachers in Babat Supat District, the $t$ value is $8.015>$ the price of the table is 1.9944 , where the $t$ value is greater than the $t$ value of the table and the 0.000 value is less than 0.05 , so Hol is accepted. So, there is a major impact among the motivating variables of the instructor on the output of the elementary school teachers in the Babat Supat District.

Discipline forms an essential role in the development of individuals who are characterized by excellence. On the basis of the above test results, it is shown that the discipline of work teachers has no effect in part and is not relevant to the performance of teachers. School discipline must be supported by factors that exist in schools, such as a positive school climate that gives teachers a sense of security and satisfaction. There will be a sense of satisfaction with the existence of a transparent promotion process. There is an increase in the welfare of teachers, which will increase the discipline of the teacher itself. There will be a sense of satisfaction with the existence of a transparent promotion process.

This report is consistent with the Damanik analysis study [15]. On the basis of the results of the data review, it is recognized that the impact of the discipline of work on the performance of teachers is $0.288=28.8 \%$. To test whether or not the effect of the work discipline of the teacher is significant. Based on the outcome of the test, it can be seen that in the Sig (significant) column in the Coefficients table above, the Sig value is 0.00 $(0.05>0.00)$. The results showed that work discipline directly affects teacher performance, which means that if teachers have a high level of work discipline, they tend to have a high level of performance.

\section{The impact of teacher motivation on teacher success}

The design for the relation between primary leadership and teacher success is represented in the form of the linear regression $\mathrm{Y}=7.965+0.805 \mathrm{X}_{3}$. The survey approach of the regression equation can be seen in the table below.

Table 3. The significance of teacher motivation variables on teacher work performance

\begin{tabular}{|c|c|c|c|c|c|c|}
\hline \multicolumn{7}{|c|}{ T Test } \\
\hline \multirow[b]{2}{*}{ Model } & & $\begin{array}{r}\text { Unstand } \\
\text { Coeffi }\end{array}$ & $\begin{array}{l}\text { rdized } \\
\text { ents }\end{array}$ & $\begin{array}{l}\text { Standardized } \\
\text { Coefficients }\end{array}$ & \multirow[b]{2}{*}{ t } & \multirow[b]{2}{*}{ Sig. } \\
\hline & & $\mathrm{B}$ & $\begin{array}{l}\text { Std. } \\
\text { Error }\end{array}$ & Beta & & \\
\hline (Constant) & 7.929 & 5.650 & & 1.403 & 0.165 & 0.044 \\
\hline Motivation & 0.807 & 0.101 & 0.684 & 8.015 & 0.000 & 0.000 \\
\hline
\end{tabular}

a. Dependent Variable: Performance

Centered on the efficiency test of the teaching discipline component of elementary school teachers in the Babat Supat District, the $t$ value is 8.146> the $t$ table price is 1.9944 where the $t$ value is More than the $t$ table and the 0.000 value is less than 0.05 , so Ho1 is approved. So that there is a major impact on the success of elementary school between the vector teaching discipline in the Babat Supat District.

Motivation is something that causes a person to take action, keeps him going, and determines the safety he's going to take. This understanding indicates that motivation is an element that guides a person to achieve the goals that he or she wants to achieve. Motivation of a teacher does not necessarily improve aspects of early childhood skills, because motivation is only an incentive for teachers or educators to work in accordance with their work and enthusiasm.

Motivation can act as a driving force for business and achievement. Someone is making an effort on the grounds of motivation. There will be good results from 
the existence of good motivation in learning. In other words, with diligent effort, and primarily motivated, someone who learns will be able to produce good achievements. Depending on the outcomes of the test in the table above, the motivation is shown of the work teacher in part has no effect and is not significant for the performance of the teacher [13].

Another study by Damayani, et al [16] stated that: (1) there is a major effects on the activities of teachers between the leadership of the principal; 2) there is a strong impact on the performance of teachers between job motivation; and 3) there is a strong impact on the performance of teachers jointly between the school leaders and work motivation.

Research is in line with the research of Ardiana [17]. This research uses a quantitative research strategy to a sample of 97 people taken from accounting teachers at SMK Madiun City by randomized cluster sampling. The results demonstrated that job encouragement had a strong impact production of reporting teachers with a commitment of $80.6 \%$ while the resulting $19.4 \%$ of the output of accounting teachers was calculated by other factors beyond the study.

\section{The impact of headmaster leadership, discipline, teacher motivation on teacher success}

The relationship model of principal leadership and teacher's motivation for teacher success is represented in the form of a linear regression $\mathrm{Y}=0.262+0.357 \mathrm{X}_{1}+$ $0.265 \mathrm{X}_{2}+0.325 \mathrm{X}_{3}$. This means that the performance of the teacher will increase positively with the principal's style of leadership, the motivation of the teacher and the discipline of the teacher.

In order to figure out the facts of the theories tests, a simultaneous test was carried out using the $F$ test to assess the accuracy of the tests. the impact of school culture variables and organizational commitment on teacher performance. The test criteria shall be (a) if the probability value (significant) is $<0.005$, then $\mathrm{Ho} 3$ is refused, and (b) if the significance level (significant) is $>0.005$, then Ho3 is accepted. The test conditions for the $\mathrm{F}$ test are as follows: (a) $\mathrm{Ha} 3$ is accepted if you have $\mathrm{F}$ count $>\mathrm{F}$ table, and (b) Ho3 is accepted if F count $\leqslant \mathrm{F}$ table is accepted. The results of the multiple regression analysis can be found in the table below.

Table 4. Significant influence of principal leadership, motivation of teachers and discipline on the performance of teachers

\begin{tabular}{|c|c|c|c|c|c|c|}
\hline \multicolumn{2}{|c|}{ Model } & \multirow{2}{*}{$\begin{array}{c}\begin{array}{c}\text { Sum of } \\
\text { Squares }\end{array} \\
1384.289\end{array}$} & \multirow{2}{*}{$\frac{\mathrm{df}}{3}$} & \multirow{2}{*}{$\begin{array}{c}\text { Mean } \\
\text { Square }\end{array}$} & \multirow{2}{*}{$\frac{F}{27.471}$} & \multirow{2}{*}{$\frac{\text { Sig. }}{.000^{\mathrm{b}}}$} \\
\hline 1 & Regression & & & & & \\
\hline & Residual & 1192.591 & 71 & 16.797 & & \\
\hline & Total & 2576.880 & 74 & & & \\
\hline
\end{tabular}

a. Dependent Variable: performance

b. Predictors: (Constant), principal leadership, motivation teachers, discipline

Based on the importance test of the principal's leadership variable, the teacher's discipline, the teacher's motivation for the performance of elementary school teachers in the Babat Supat District, it is established that the $\mathrm{F}$ value is $27.471>$ the $\mathrm{t}$ table price is 2.73 where the calculated $\mathrm{F}$ value is greater than the $\mathrm{F}$ table and the significance value is 0.000 lower than 0.05 when the Ho1 value is accepted so that the F value is higher than the $\mathrm{F}$ table.

Table 5. Summary model of leadership, motivation, discipline

\begin{tabular}{llrrr}
\hline Model & R & R Square & $\begin{array}{r}\text { Adjusted } \\
\text { R Square }\end{array}$ & $\begin{array}{c}\text { Std. Error } \\
\text { of the } \\
\text { Estimate }\end{array}$ \\
\hline 1 & $.733^{\mathrm{a}}$ & 0.537 & 0.518 & 4.09842 \\
\hline & \multicolumn{4}{l}{ a. Predictors: (Constant), leadership, motivation, discipline }
\end{tabular}

Figure out how much impact the regression coefficient has on the predictor variables, see the summary table above. The table above shows the value of $\mathrm{R}$, which is a symbol of the value of the correlation coefficient. At the value above the correlation value is 0.733 This value can be interpreted as meaning that the connection between the two study variables is in a strong category. This table also shows the value of the 
square $\mathrm{R}$ or the coefficient of determination (KD) which shows how well the regression model is generated by the interaction of the independent variables and the dependent variable. The KD calculated value is 0.537 which can be viewed as an independent variable. $\mathrm{X}$ has a contribution effect of 53.7 per cent on variable $\mathrm{Y}$ and 46.3 , while the other per cent is influenced by factors other than variable $\mathrm{X}$.

The results of due diligence on the variables of primary leadership, teacher motivation and teacher discipline on teacher performance have acquired a value of significance lower than the predetermined level of relevance, and it can be inferred that leadership, inspiration of the principal and discipline of the instructor are collective. The same has no effect and is not relevant to the performance of the teacher so that it can be concluded that the first hypothesis is rejected.

The higher the main leadership variable, the motivation of teachers and the discipline of teachers in the Babat Supat District, it turned out that it did not affect the performance of teachers equally. The higher the main leadership variable, the motivation of the teacher and the discipline of the teacher will not have much effect on the performance of the teacher.

This means that, to increase the productivity of educators, they must do so by their own will, strengthen the desire for progress and develop. Performance must be formed by each teacher, the leader in this case only advises without imposing sanctions to increase the performance of the teacher.

This is not in line with Setiawan's research [18] impact of discipline of work and encouragement on employee performance at the Malang Regional General Hospital in Kanjuruhan. The results of his studies indicate discipline and motivation at work do not simultaneously influence employee performance.

This is consistent with research by Alhusaini, et al. [19]. Results have shown that: 1) there is a significant effect of work motivation on the performance of teachers; 2) there is a significant effect of the discipline of work on the performance of teachers; 3 ) there is a significant influence on the performance of teachers between work motivation and work discipline.

Research by Marce et al found that: 1) policy formulation; 2) Arrangement of the Principal of SDN 3 Babat Toman shall be carried out by the Principal by dividing the tasks according to the competence in their respective fields, 3) Supervision of the Principal of SDN 3 Babat Toman shall be carried out directly to teachers and students through morning breaks, monitoring the activities of students and teachers by monitoring each class. Supervision at the beginning of the preparation can minimize the possibility of failure that can occur when the implementation of school activities in the future [20].

\section{CONCLUSION}

On the basis of the findings of the research and debate, the follows could be reached the conclusion: 1) the leadership of the principal affects the performance of teachers in the SD Babat Supat District of Musi Banyuasin Regency; 2). The effect of work motivation is on the performance of teachers in SD Babat Supat District, Musi Banyuasin Regency; 3) work discipline has an effect on the effectiveness of teachers in SD Babat Supat District, Musi Banyuasin Regency; and 4) key leadership, work motivation and work discipline influence the success of teachers. in SD Babat Supat District, Musi Banyuasin District.

\section{ACKNOWLEDGMENT}

Our deepest gratitude goes to Teachers in SD Babat Supat District, Musi Banyuasin Regency, Chancellor of Palembang PGRI University, Director of the Postgraduate Program of PGRI Palembang University and the Education Management Study Program of PGRI Palembang University, who have supported us in doing this extraordinary thing. This project is funded independently. We also want to thank our Education Management friends who helped us a lot in a short time frame to complete this project.

\section{REFERENCES}

[1] Danim, S. (2002). Inovasi Pendidikan: dalam Upaya Meningkatkan Profesionalisme Tenaga Kependidikan [Educational Innovation: in an Effort to Improve the Professionalism of Education Personnel]. Bandung: Pustaka Setia.

[2] Zuryati. (2015). Gaya Kepemimpinan Kepala Sekolah Dalam Meningkatkan Kinerja Guru Pada Sdn 7 Muara Dua Lhoksuemawe [Leadership Style of the Principal in Improving Teacher Performance at SDN 7 Muara Dua Lhoksuemawe]. J. Adm. Pendidik. Progr. Pascasarj. Unsyiah, vol. 3, no. 2, pp. 78-102.

[3] Purnama, B. J. (2016). Optimalisasi Manajemen Sumber Daya Manusia dalam Upaya Peningkatan Mutu Sekolah [Optimizing Human Resource Management in Efforts to Improve School Quality]. J. Manaj. Pendidik., vol. 12, no. 2, pp. 24-37.

[4] Ruliaty, S. S. (2016). Pengaruh Gaya Kepemimpinan Kepala Sekolah, Budaya Sekolah, Dan Disiplin Guru Terhadap Kinerja Guru Pada Sekolah Menengah Kejuruan (Smk) Negeri I Jeneponto [The Influence of Principal Leadership Style, School Culture, and Teacher Discipline on Teacher Performance at Public Vocational High 
Schools (Smk) Negeri I Jeneponto]. J. Compet., vol. 10, no. 2, pp. 120-131.

[5] Supeno., Suseno, I., \& Miranti, I. (2017). Pengaruh Motivasi, Disiplin Kerja, Dan Gaya Kepemimpinan Kepala Sekolah Terhadap Kinerja Guru Bahasa Inggris Smp Dki Jakarta [The Influence of Motivation, Work Discipline, and Principal Leadership Style on the Performance of English Teachers at SMP Dki Jakarta]. J. DEIKSIS, vol. 9, no. 1, pp. 90-99.

[6] Gibson, I., \& Donnely. (1998). Organisasi dalam Manajemen [Organization in Management]. Jakarta: Erlangga.

[7] Adeyemi. (2010). Principal' leadership styles and teachers' job performance in senior secondary schools in Ondo State, Nigeria. J. Educ. Res., vol. 2, no. 2, pp. 83-91.

[8] Handayani, T., Rasyid., \& Aliyah, A. (2015). Pengaruh Kepemimpinan Kepala Sekolah, Motivasi Guru, Dan Budaya Organisasi Terhadap Kinerja Guru Sma Negeri Wonosobo [The Influence of Principal Leadership, Teacher Motivation, and Organizational Culture on the Performance of Wonosobo State High School Teachers]. J. Akuntabilitas Manaj. Pendidik. Vol., vol. 3, no. 2, pp. 264-277.

[9] Musfiqon, H. M. (2012). Metodologi Penelitian Pendidikan [Educational Research Methodology]. Jakarta: PT Prestasi Pustakaraya.

[10] Imansyah., Arafat, Y., \& Wardiah, D. (2020). Pengaruh Kepemimpinan Kepala Sekolah Dan Partisipasi Komite Sekolah Terhadap Kinerja Guru [The Influence of Principal Leadership and School Committee Participation on Teacher Performance]. JMKSP (Jurnal Manajemen, Kepemimpinan, dan Supervisi Pendidikan), vol. 5, no. 2, p. 135, doi: 10.31851/jmksp.v5i2.3756.

[11] Suratman., Arafat, Y., \& Eddy, S. (2020). The Influence of Principal' s Leadership and Teacher' $s$ Competence toward Teacher' $\mathrm{s}$ Performance in Indonesia. Journal of Social Work and Science Education Volume 1 (2) pp 96-104. E-ISSN: 27236919.

[12] Sardiman. (2011). Interaksi dan motivasi belajar Mengajar [Teaching and learning interaction and motivation]. Jakarta.: Raja Grafindo Persada.

[13] Kartini., Ahmad, S., \& Eddy, S. (2020). Pengaruh Gaya Kepemimpinan Kepala Sekolah dan Komunikasi Interpersonal Terhadap Kinerja Guru [The Effect of Principal Leadership Style and Interpersonal Communication on Teacher
Performance]. J. Educ. Res., vol. 1, no. 3, pp. 290294, doi: 10.33753/mandiri.v3i2.85.

[14] Damayani, T., Arafat, Y., \& Eddy, S. (2017). Pengaruh Kepemimpinan Kepala Sekolah Dan Motivasi Kerja Terhadap Kinerja Guru [The Influence of Principal Leadership and Work Motivation on Teacher Performance]. J. Adm. Pendidik. Progr. Pascasarj. Unsyiah, vol. 5, no. 3, pp. 46-57.

[15] Ardiana \&Eka, T. (2017). Pengaruh Motivasi Kerja Guru Terhadap Kinerja Guru Akuntansi Smk Di Kota Madiun [The Effect of Teacher Work Motivation on the Performance of High School Accounting Teachers in Madiun City]. J. Akunt. Dan Pajak, vol. 17, no. 2, p. 14.

[16] Damanik, R. (2019). Pengaruh Disiplin Kerja Terhadap Kinerja Guru [The Effect of Work Discipline on Teacher Performance]. J. Serunai Ilmu Pendidik., vol. 5, no. 2.

[17] Setiawan, A. (2013). Pengaruh Disiplin Kerja Dan Motivasi Terhadap Kinerja Karyawan Pada Rumah Sakit Umum Daerah Kanjuruhan Malang [The Influence of Work Discipline and Motivation on Employee Performance at Kanjuruhan Regional General Hospital Malang]. J. Ilmu Manaj., vol. 1, no. 4.

[18] Alhusaini, A., Kristiawan, M., \& Eddy, S. (2020). Pengaruh Motivasi Kerja dan Disiplin Kerja terhadap Kinerja Guru [The Effect of Work Motivation and Work Discipline on Teacher Performance]. J. Pendidik. Tambusai, vol. 4, no. 3, pp. 2166-2172.

[19] Marce, S., Ahmad, S., \& Eddy, S. (2020). Manajemen Kepemimpinan Kepala Sekolah Sebagai Administrator Dalam Peningkatan Kompetensi Guru [Leadership Management of Principals as Administrators in Improving Teacher Competence]. Dawuh Islam. Educ. J., vol. 1, no. 2, pp. 76-81.

[20] Sarbini., Kristiawan, M., \& Wardiah, D. (2020). Supervisor's Performance for the Quality of Education. International Journal of Progressive Sciences and Technologies (IJPSAT), 20(1), 255262. 